P 166

\title{
イソプロピルアルコール、トルエン吸入䀧露ラットにおける 血中溶肪濃度および尿中代謝物の測定
}

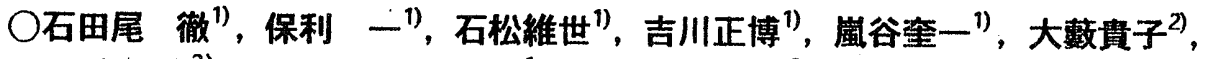 \\ 田中勇武 ${ }^{2)}$ (産医大 $\cdot{ }^{1}$ 産業保健学部 ${ }^{2}$ 産業生態科学研究所)
}

【はじめに】演者らはこれまで、シンナ一の代表的な成分であるメ夕ノールートルエン、 MEK-トルエンの2成分混合䓠気をラットに吹入曝露し、血中溶剤濃度および尿中代謝 物の量を経時的に測定することにより、それぞれの物質の生体内における相互作用につ いて検討してきた。本報では、イソプロピルアルコール(IPA)-トルエン系について吸入 曝露実験を行い、同様の検討を行ったので報皆する。

【方法】Wistar系雄ラットを単独(トルエン、IPA)溶剤曝露群、混合溶剤曝露群、対照群 ( $n=5$ /群)の4群に分けた。ステンレス製の曝露チャンバー(容積 $100 \mathrm{~L}$ )内に一定濃度の蒸 気を導入し、吸入曝露を行った。曝露濃度はIPA500ppm、トルエン500ppmとした。チャ ンバー内の蒸気濃度をFID付ガスクロマトグラフ(日立G5000)で定期的にモニターした。 嚗露時間は1日6時間とし、4週間(5日/週)曝露を行った。嚗露終了後、尾部より血液を経 時的に採取するとともに、尿を採取した。血中の溶剤濃度はへッドスペース法により、 GC/MS(島津GCMS-QP5050)を用いて测定した。また、尿は曝露終了直後、曝露終了18 および41時間後に採取し、尿中のIPAはGC/MS、トルエンの代表的な代謝物である馬尿 酸の量は高速液体クロマトグラフ(日立L-4000)で測定した。

【結果および考察】図 1 および図 2 に血中IPAおよびトルエン濃度の経時変化をそれぞ れ示す。血中IPA濃度は、曝露直後は単独、漉合曝露雨群で差はなかったが、半減期に ついては単独曝露の方がわずかに短かった。これはこれまでに得られた、MEK-トル工 ン系およびメタノール-トルエン系の結果と同様の傾问である。一方、血中卜ルエン濃 度の半減期については混合曝露の方が䂑かった。また、混合曝露の尿中馬尿酸排泄速度 は、単独嚗露と比較すると曝露直後は高かったが、すみやかに減少する傾问が見られた。 以上の結果から、IPAの共存によってトルエンの代謝が促進されることが示唆された。

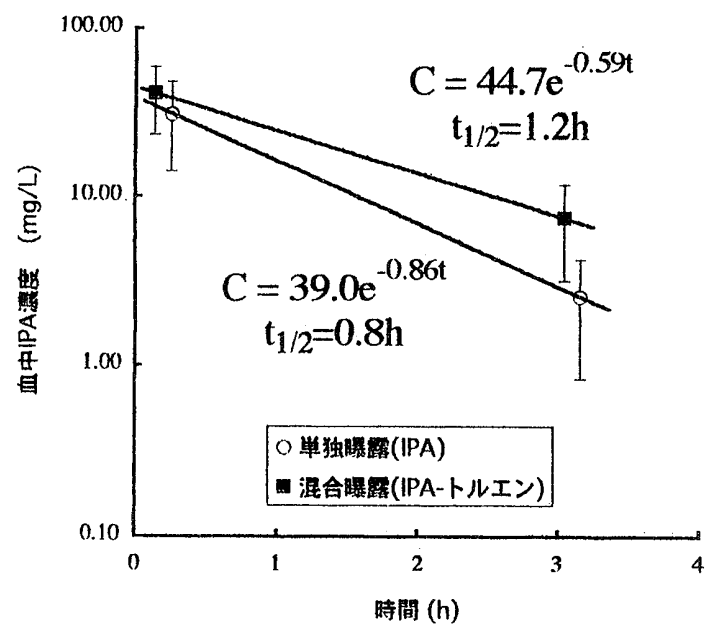

图 1 血中IPA濃度の経侍変化

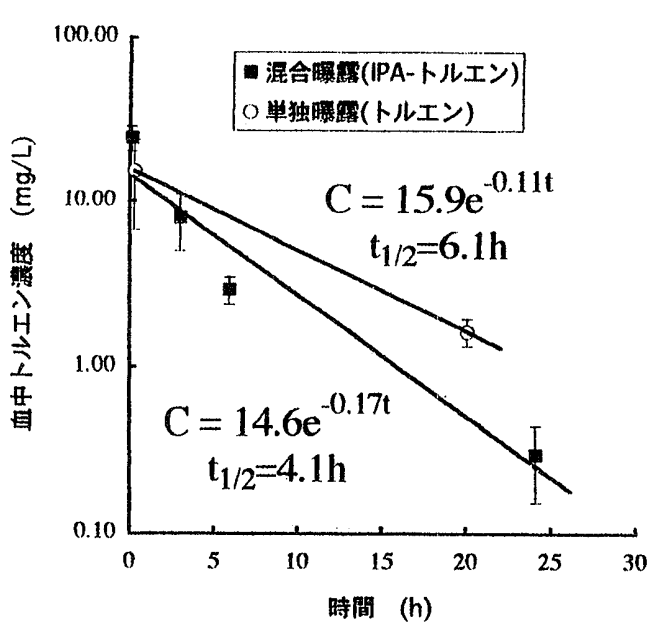

図 2 血中トルエン濃度の経時変化 